\title{
Jornalismo em questão
}

Desde junho de 2009, quando o Supremo Tribunal Federal

julgou como inconstitucional a exigência de diploma para 0 exercício da profissão de jornalista, 0 debate sobre 0 jornalismo ficou particularmente aceso no Brasil. Em diversos fóruns, profissionais do ramo e pesquisadores da área dedicaram-se a analisar a sentença judicial e a discutir não somente a prática jornalística, mas também as teorias e a pesquisa sobre jornalismo. Afinada com esse debate, a E-Compós lançou chamada sobre a temática, convidando pesquisadores da área a refletir sobre os estudos e a práxis jornalística atual.

A edição que ora se apresenta traz cinco trabalhos que comportam diversas abordagens dentro do jornalismo, aprofundando a reflexão sobre o tema e fomentando novos debates. No artigo de abertura, intitulado "O agendasetting no Brasil: contradições entre o sucesso e os limites epistemológicos", Kênia Maia e Luciane Agnez discutem a apropriação do conceito de agenda-setting nos estudos brasileiros sobre jornalismo, questionando sobretudo a ênfase comumente dada à análise dos processos de produção das notícias, negligenciando as complexidades e os desafios dos processos de recepção e usos sociais das mesmas. 0 debate proposto pelas autoras, focado fundamentalmente sobre as 
pesquisas da área, abre caminho para uma discussão sobre a qualidade na prática jornalística, que também perpassa questionamentos sobre a contribuição que os pesquisadores de jornalismo podem dar à temática. Em "Sistema de Gestão de Qualidade aplicado ao Jornalismo: possibilidades e diretrizes", Josenildo Guerra analisa as dificuldades que cercam 0 desenvolvimento de um sistema de gestão e avaliação de qualidade no jornalismo e elabora uma proposta preliminar baseada numa definição de qualidade ancorada em dois requisitos básicos: verdade e relevância.

0 recorrente conceito de "verdade" é discutido também por Francisco Rui Cádima no artigo "Jornalismo televisivo e crime violento, ou sobre um decisivo "não-dito", onde apresenta um debate sobre a relação entre violência e telejornalismo a partir de um caso português. Rejeitando parcialmente a atribuição de uma relação mimética entre mídia e violência, 0 autor discute efeitos de curta e longa duração na veiculação do que chama de uma "realidade trágica", que caracterizam uma regularidade enunciativa mais do que uma ação com consequências diretas. Entram em pauta, então, as decisões de agenda, tomadas a partir de diversos fatores, incluindo a negociação "não-dita" entre memória e esquecimento.

0 "agendamento" também é feito sobre a produção da notícia, através da ação de grupos de interesse no cotidiano dos jornais. No texto "A financeirização do noticiário econômico: 0 uso de estratégias de comunicação por grupos de interesse e seu impacto nos conteúdos jornalísticos", Paula Puliti discute as implicações que o predomínio de um grupo de interesse no noticiário econômico tem sobre o caráter de pluralidade que a imprensa desfruta em ambientes democráticos, caracterizando uma visão predominantemente neoliberal cuja consequência é a financeirização das notícias. 
Finalizando a edição, o artigo de Leticia Matheus apresenta um debate sobre a relação do jornal com o tempo, tanto tomado em sentido histórico, quanto em seus aspectos simbólicos e sobretudo em sua dimensão climática. Sob o título "A chegada do inverno ou o que tenho a ver com Kuala Lumpur?", a autora estabelece uma tipologia das funções do tempo no jornal (pragmáticas, historiográficas e cosmológicas, de medição e mediação do tempo) indicando que os jornais servem para oferecer um conforto simbólico de domínio do tempo e que dessa função depende também seu status, bem como sua inteligibilidade.

Acreditamos que os artigos aqui publicados apresentam uma pequena amostra de altíssima qualidade sobre a produção científica voltada para os estudos de jornalismo e que, dessa maneira, a E-Compós está contribuindo para a difusão e ampliação das questões desse fascinante tema de pesquisa de nossa área.

Boa leitura, 